\title{
PROBLEM CIERPIENIA \\ W PERSPEKTYWACH WHITEHEADOWSKIEJ FILOZOFII PROCESU
}

W próbach filozoficznej interpretacji świata jako jedno z najtrudniejszych i najbardziej subtelnych problemów jawi się zagadnienie cierpienia i zła. Rozwijane w perspektywach różnych systemów dociekania dotyczące racjonalności świata, matematycznego charakteru przyrody, porządku, celowości, etc. natrafiają na zasadniczą trudność w zetknięciu z konkretną rzeczywistością ludzkiego niezawinionego bólu. Racjonalny ciąg logicznych argumentów załamuje się przy bólu matki opłakującej śmierć jedynego dziecka czy doświadczeniu samotnego protestu osoby pozbawionej możliwości ruchu. W różnorodnych systemach filozofii poszukuje się różnych środków interpretacyjnych, które umożliwiałyby określenie ontycznych uwarunkowań cierpienia. W świetle współczesnych analiz z zakresu filozofii języka jest oczywiste, że możliwości eksplanacyjne poszczególnych systemów zależą w dużym stopniu od przyjętych w nich języków oraz zbiorów założeń podstawowych ${ }^{1}$. Problematyka, która wydaje się niewytłumaczalna czy irracjonalna przy stosowaniu relatywnie ubogiego języka $J_{i}$ może w niektórych przypadkach okazać się rozstrzygalną po wprowadzeniu bardziej subtelnych dyferencjacji popojęciowych na gruncie bogatszego języka $J_{k}$.

Zagadnienie, które chcę przebadać w tym artykule sprowadza się do kwestii: Czy po przyjęciu kategorii pojęciowych wypracowanych w Whiteheadowskiej filozofii procesu nie można by wytłumaczyć niektórych aspektów ludzkiego cierpienia w sposób bardziej zadowalający niż czyni się to w klasycznych systemach metafizyki? Wydają się istnieć poważne racje upoważniające do pozytywnej odpowiedzi na postawione pytanie.

\section{PODSTAWOWE ZAEOŻENIA FILOZOFII PROCESU}

Celowość wykorzystania kategorii metafizycznych zaproponowanych w 1927 r. przez A.N. Whiteheada akcentował na polskim gruncie filozo-

1 Por. np. F. Suppe, Alternatives to Received View, [w:] The Structure of Scientific Theories, Chicago 1977, $159 \mathrm{n}$. 
ficznym m.in. Kazimierz Kłósak. W ostatnim okresie swej pracy naukowej opowiadał się on za możliwością wykorzystania wizji świata ukazywanej $\mathrm{w}$ Process and Reality do wypracowania nowych interpretacji istotnych dla myśli chrześcijańskiej ${ }^{2}$. Smierć uniemożliwiła zrealizowanie tego planu, niemniej pozostaje faktem, iż w odmiennym kontekście jest on realizcwany przez filozofów amerykańskich. Zainicjowany przez Whiteheada nurt zwany filozofią procesu stanowi obecnie jeden $\mathrm{z}$ dominujących kierunków w panoramie filozoficznej myśli amerykańskiej. Prace Ch. Hartshorne'a, J. Cobba, B.M. Loomera, L. Forda, S. Ogdena, W. Stokesa czy D. Williamsa dostarczyły wielu konkretnych propozycji nowego ujęcia problematyki, której wcześniejsze opracowania na gruncie teizmu chrześcijańskiego trudno było uznać za zadowalające ${ }^{8}$. Mimo iż we współczesnej filozofii procesu występuje już zróżnicowanie stanowisk i interpretacji, to jednak możliwe jest określenie najbardziej ogólnej wizji zawierającej tezy ontologiczne przyjmowane przez prawie wszystkich filozofów tego nurtu ${ }^{4}$.

Swiat bytów realnych nie jest traktowany w filozofii Whiteheada jako zbiór trwałych i niezmiennych substancji. Podstawowe kategorie Process and Reality pozostają bliższe mechanice kwantowej niż substancjalistycznemu ujęciu Arystotelesa. Ontologiczny odpowiednik kwantów stanowią byty aktualne (zwane też zaistnieniami aktua lnymi) - najmniejsze jednostki, jakie można wyróżnić w ontycznej strukturze świata. Rzeczywistość, która w codziennym doświadczeniu jawi się nam w postaci stołów, kamieni czy kwiatów, w perspektywach metafizyki procesu traktowana jest jako ciągi bytów aktualnych. O tym, że byty te nie występują w izolacji lub w chaotycznym zamieszaniu, decyduje złożona sieć ujęć (prehensions) między nimi. Każdy wyłaniający się byt aktualny pozostaje w określonym ujęciu (odniesieniu) w stosunku do wcześniejszych bytów oraz w pewnej relacji do idealnych wzorców rozwoju określanych przez tzw. obiekty ponadczasowe stanowiące odpowiednik Platońskich idealnych form. W przypadku odniesień pierwszego typu mówimy o ujęciu fizycznym, z racji fizycznego charakteru związków z przeszłością. W odniesieniach drugiego typu - o ujęciu pojęciowym (conceptual). Jeśli w procesie rozwoju dominują ujęcia fizyczne, teraźniejszość jest w większym stopniu powtórzeniem albo kontynuacją przeszłości. Kiedy główną rolę odgrywają ujęcia pojęcio-

${ }^{2} \mathrm{~K}$. Klósak, Stowo końcowe - próba konfrontacji, „St. Phil. Christ.” $17 / 1$ (1981), 178.

3 Odsyłacze do poszczególnych prac wymienionych autorów można znaleźć w drugim tomie pracy J. Ż yciński, Teizm $i$ filozofia analityczna, Kraków 1987.

${ }_{4}^{4}$ Dokładniejszą charakterystyke podstawowych kategorii ontologii Whiteheada przedstawiłem w III rozdz. 2 tomu pracy: Teizm $i$ filozofia analityczna. 
we, w procesie rozwoju następuje emergencja nowych, nie występujących wcześniej cech.

W dalszych uściśleniach metafizyki Whiteheada wyróżnia się ujęcia negatywne i pozytywne. W pierwszym przypadku dane zostają włączone jako element konstytuujący nowe byty aktualne, zaś wyłaniająca się rzeczywistość ma charakter odtwórczy. W przypadku drugim pewne dane zostają wykluczone $\mathrm{z}$ nowo powstającej syntezy, w której ujawniać się może przez to $\mathrm{w}$ większym stopniu element nowości i rozwoju. Pozytỵwne ujęcia są określane synonimicznie mianem ,odczuć” (feelings), który to termin bywa niekiedy niesłusznie uważany za przejaw panpsychizmu w ontologii Whiteheada.

W procesie poznawania rzeczywistości jesteśmy złączeni z przeszłością przez ujęcia fizyczne i otwarcie na novum realizowane w aktach ujęc pojęciowych poprzez odniesienie do obiektów ponadczasowych. Przeszłość i przyszłość, determinizm historii oraz ideały i wartości niezależne od czasu łączą się i przenikają w ulotnych momentach doświadczenia odpowiadających aktualnym zaistnieniom. Zaistnienia te nie są przeżywane przez nas jednostkowo, w wyizolowanych dawkach, lecz tworza ciągi (nexūs). Ciągi te mogłyby stanowić przypadkową mieszaninę nieskoordynowanych zdarzeń i wówczas świat, w którym żyjemy byłby niezorganizowanym chaosem niedostępnym dla jakichkolwiek prób racjonalnego opisu. To, że zamiast chaosu wszechświat ma stabilne struktury dające się ująć w racjonalnej refleksji, można wyjaśnić dopiero po przyjęciu tezy o istnieniu ontycznej podstawy racjonalności świata.

Pasywny czynnik określający potencjalne możliwości rozwoju istniejących struktur ontycznych nazywa Whitehead pierwotnym aspektem natury Bożej ${ }^{5}$. Aktywny czynnik organizujący ciągi bytów aktualnych w stabilne i racjonalne struktury nazywa on wtórnym aspektem natury Bożej $^{6}$. W ujęciu takim Bóg filozofów nie jest jedynie transcendentnym Absolutem czy nieruchomym Poruszycielem. Prawda o Jego transcendencji wyraża się $w$ tym, iż zbiór możliwości określanych w pierwotnym aspekcie Bożej natury jest zbiorem bogatszym od maksymalnego zbioru fizycznych realizacji w przyrodzie. Metafizyka procesu akcentuje jednak w sposób szczególny prawdę o Bożej immanencji. Bóg, określony przez Whiteheada mianem poety świata, prowadzi realizowane ciągi bytów aktualnych ku Boskim ideałom harmonii. Jest On immanentną zasadą organizującą, która wchodzi w sieć ujęć z ciągami bytów aktualnych, od-

${ }^{5}$ Sam Whitehead używa wprawdzie wyrażenia ,primordial nature”, lecz jego komentatorzy podkreślają zgodnie, iż nie chodzi tu o naturę w klasycznym sensie, lecz o jej aspekt lub stan.

"Przetłumaczenie ,consequent nature" jako „wtórna natura" prowadziłoby bezpodstawnie do skojarzeń z okresu sporu z monofizytyzmem.

11 - Analecta Cracoviensia 
działywając przede wszystkim poprzez ujęcia pojęciowe. Ich realność przejawia się $\mathrm{w}$ tym, iż zostajemy zafascynowani przez pewne wartoścí czy decydujemy się dążyć ku trudnym ideałom. Decyzje te mogą być jednak osłabiane lub wręcz odrzucane w wyniku innych oddziaływań np. fizycznych obciążeń, które sprawiają, że wybieramy prozaiczną drzemkę zamiast altruistycznych działan.

We współdziałaniu z rzeczywistością ludzkiego bytu Bóg nie narusza nigdy naszej wolności. Whitehead akcentuje mocno, iż podstawową formą Bożego działania jest perswa zja, nie zaś przymus. W wyniku tego człowiek może zawsze odrzucić wzorce harmonii i piękna proponowane przez Subtelnego Poetę Świata oraz może wybrać własne wzorce doskonałości naznaczone piętnem środowiska, cech osobowościowych czy obciążeń dziedzicznych.

Zasadnicze pytanie, jakie jawi się w metafizyce procesu, dotyczy kwestii, czy możliwe byłoby znalezienie innych, lepszych korelacji między ideałami określonymi $\mathrm{w}$ pierwotnym aspekcie natury Bożej i ideałami wybieranymi przez człowieka? Konkretyzując tę kwestię można pytać: Przy jakich uwarunkowaniach ontologicznych dałoby się uniknąc (wszystkich lub przynajmniej niektórych) przejawów cierpienia występujących w obiektywnej rzeczywistości? Sam Whitehead nie podjął bezpośrednio tej kwestii. Przy próbie jej interpretacji będę więc odwoływał się do podstawowych tez przyjmowanych $\mathrm{w}$ jego systemie, nie zaś do bezpośrednich gotowych tłumaczeń.

\section{CIERPIENIE JAKO ONTYCZNA NIEZUPEENOSC SYSTEMU SWIATA}

Zło jako takie nie jest traktowane $\mathrm{w}$ metafizyce procesu $\mathrm{w}$ kategoriach ontycznego niebytu. Jedynie zło moralne można uważać za brak odpowiedniego dobra moralnego, które zostało wyeliminowane bądź to przez akt ludzkiej woli, bądź przez sytuacyjne uwarunkowania. W naszym doświadczeniu różnorodnych form zła i towarzyszącego im cierpienia zbyt łatwą interpretacją byłoby przyjęcie tezy głoszącej, iż zło jest jedynie brakiem odpowiedniego bytu. Rzeczywistość zła doświadczana w bólu stworzenia jest niemniej realna niż rzeczywistość dobra. Doświadczenie jej przejawów prowadzi często do opinii o absurdalności świata pozostającej w oczywistej dysharmonii $\mathrm{z}$ tezą Leibniza o tym, iż nasz wszechświat jest najlepszy z możliwych. Niektórzy z kontynuatorów optymistycznych ujęć Leibniza przesuwają akcent ze słowa „najlepszy” na słowo „możliwy". Tym samym sugerują oni, iż nieuchronnym następstwem wielorakich ograniczeń ontycznych występujących w procesie rozwoju świata musi być doświadczenie bólu i zła. Powstaje pytanie czy afirmacja tej 
konieczności nie jest jedynie wyrazem wygodnych, lecz całkowicie arbitralnych założeń? Czy tradycyjne wyobrażenia o rzeczywistości wolnej od bólu i cierpień trzeba uznać definitywnie za formę utopii nie liczącej się $\mathrm{z}$ wielorakimi ograniczeniami struktur ontycznych, od których zależy nasz byt?

Zbyt wielki jest zbiór niewiadomych, by móc odpowiedzieć, w jakim stopniu nasz świat mógłby stanowić pełniejszą realizację ideałów doskonałości, racjonalności i sensu. Zbyt mało znamy wzajemne ograniczenia między różnymi poziomami bytu, aby rozwijać projekty alternatywnych struktur ontycznych. Uważam jednak, iż odkryte w naszym stuleciu limitacyjne twierdzenia metalogiki dostarczają bardzo ważnych analogii ukazując istnienie nieznanych uprzednio ograniczeń, które uniemożliwiają całkowite wyeliminowanie przejawów niedoskonałości. Niezależnie od tego, jak ujmuje się relacje między logiką i ontologią, tradycyjne marzenia logików o zupełności i niesprzeczności systemów logicznych stanowiły odpowiednik marzeń metafizyków o świecie, w którym nie występowałby nonsens ani sprzeczność, gdyż wszystkie zdarzenia miałyby racjonalne wyjaśnienie i były spójne ze strukturą tworzoną przez pozostałe wydarzenia. Zupełność systemów logicznych przejawiająca się w tym, iż $z$ przyjętego zbioru aksjomatów dałoby się wyprowadzić bądź to interesujące nas twierdzenie, bądź jego negację, stanowiłaby logiczny odpowiednik racjonalności świata przejawiającej się $w$ tym, iż jego dowolny stan można racjonalnie wytłumaczyć lub uzasadnić przez odwołanie do niewielkiego zbioru podstawowych zasad. Niesprzeczność bogatych systemów logicznych przejawiająca się $\mathrm{w}$ tym, iż nie można w ramach określonego systemu przyjąc zdania $\mathrm{A}$ i jego negacji $\sim \mathrm{A}$, byłaby logicznym odpowiednikiem tych ontycznych własności świata, dzięki którym w jego rozwoju nie występowałyby sytuacje rozdarcia i absurdu.

Dobrze znane prace D. Hilberta świadczą, iż jeszcze w początkach naszego stulecia czołowym logikiem wydawało się, że wykazanie zupełności bogatych systemów logicznych czy niesprzeczności arytmetyki jest jedynie kwestią czasu i wysiłku. Odkrycia Gödla z 1931 roku oraz późniejsze prace Tarskiego odsłoniły bezlitośnie i szokująco iluzoryczność podobnych oczekiwań. Nawet logika naznaczona jest piętnem niedoskonałości i niespodziewanych ograniczeń. Tylko trywialne i mało interesujące systemy logiczne są zupełne. Niesprzeczności arytmetyki nie można wykazać przy pomocy technik skończonych; trzeba jak w dowodzie Gentzena uwzględnić elementy pozaskończone wprowadzając indukcję do $\varepsilon_{0}$. W poszukiwaniu dowodu niesprzeczności systemów konieczna jest ich transcendencja, tzn. wyprowadzenie środków dowodowych nie należących do systemu. W tym kontekście naturalna wydaje się analogia, iż 
odkrycie ostatecznego sensu świata możliwe jest dopiero po uwzględnieniu czynnika Bożej transcendencji ${ }^{7}$.

Gödlowskie odkrycie niezupełności logiki wnosiło zaskakujący dysonans do wcześniejszych optymistycznych oczekiwań logików. Dziedzina, którą uważano za realizację najwyższej racjonalności okazała się niezupełna przy statycznym ujęciu. Nasze aspiracje poznawcze będą zawsze przewyższać informacyjną zawartość poszczególnych systemów logicznych. $\mathrm{Na}$ niektóre ze stawianych pytań nie można wyprowadzić żadnej odpowiedzi z przyjętych wcześniej aksjomatów. Częściowej próby przełamania tego ograniczenia można szukać w podejściu diachronicznym odwołując się do sukcesywnego rozszerzania wprowadzonej aksjomatyki i stopniowego rozstrzygania niejasnych kwestii. Podobna kreatywność nie usuwa jednak niezupełności, lecz tylko stanowi formę przeciwdziałania jej; w rozszerzonych systemach istnieją nowe zdania nierozstrzygalne, dla których rozstrzygnięć trzeba szukać w kolejnych rozszerzeniach systemów.

Przeciwko proponowanej przeze mnie interpretacji można wysunąć zarzut, iż jej słabą stroną jest wykorzystywanie argumentów z analogii obciążonych wiadomymi słabościami. Wyprzedzając podobne zarzuty chcę podkreślić, iż w przedstawionym ujęciu czynnik analogii odgrywa drugorzędną, nieistotną rolę. Elementarnym faktem pozostaje natomiast niemożność zrealizowania tradycyjnych marzeń logików o idealnych (tj. niesprzecznych i zupełnych) bogatych systemach logiki. Uważam, iż odkryte w naszym stuleciu nieuchronne ograniczenia wszelkiej formy racjonalnego dyskursu mają swe odpowiedniki również w dyskursie filozofii bytu opisujaccym ontyczne struktury świata, w którym żyjemy. W konsekwencji sądzę, że ograniczenia ukazywane przez twierdzenia limitacyjne muszą posiadać ontyczne odpowiedniki nawet wówczas gdyby rzeczywisty świat miał stanowić realizację najwyższej możliwej racjonalności. Marzenia o doskonałym wszechświecie, w którym nie byłoby bólu czy zła, są wyrazem przed-Gödlowskiej optymistycznej ontologii zacierającej różnice między marzeniami i rzeczywistością. Tak jak nietrywialnych systemów logiiki wszechmocny Bóg nie może uczynić zupełnymi właśnie dlatego, że jest Bogiem racjonalności i sensu, podobnie na wyższych poziomach bytu niemożliwe jest bez popadania w wewnętrzną sprzeczność usunięcie wszelkich przejawów niedoskonałości i zła. Na relatywnie niskim poziomie istnienia atomów czy kamieni byt ukazuje się

7 Por. uwagi jakie wypowiada R. C ha uvin w L'Esprit et la science; Colloque de Fès, Paris 1983. Twierdzi on m.in.: „Religia jest ze swej istoty poszukiwaniem sensu $[\ldots]$ Poszukiwanie sensu jest konieczne, gdyż byłoby to nieracjonalne, gdyby człowiek żył tak jak gdyby sens nie istniał. W dziedzinie tej występuje pewne podobieństwo $z$ twierdzeniami Gödla. Przejawia się ono w tym, że usprawiedliwienia egzystencji nie można znaleźć w niej samej" (s. 386). 
jako rzeczywistość wolna od dramatu i cierpienia. Ze wzrostem świadomości i z wystąpieniem procesów świadomych, podobnie jak w logice w systemach izomorficznych z Principia Mathematica, pojawia się niedoskonałość i ból ontycznej niezupełności, doświadczany czy to w fizycznym ograniczeniu czy w niezależnych od niego psychicznych frustracjach.

$\mathrm{W}$ perspektywach filozofii procesu $\mathrm{w}$ odmienny sposób do podobnych wniosków dochodzi A.R. Peacocke zwracając uwagę na występowanie strukturalnych konieczności w rozwoju wszechświata. Następstwem towarzyszących im nieuchronnych ograniczeń jest doświadczenie cierpienia. Wraz z postępem ewolucji powstają gatunki o wyższej wrażliwości i ,zwiększonej podatności na ... ataki ze strony bakterii, wirusów i innych organizmów, które - chociaż mniej wrażliwe - są jednak lepiej uzbrojone. Ból okazuje się więc nieodłącznym współtowarzyszem wzrostu wrażliwości i świadomości stanowiących konieczne warunki rozwoju świadomości" " . Strukturalna konieczność znajduje wyraz w tym, iż pewne formy biologiczne giną po to, aby na ich miejscu mogky zjawić się inne, wyższe formy.

Po ewentualnym przyjęciu tej argumentacji stajemy nadal przed pytaniem, czy ontyczna niezupełność świata nie mogłaby znaleźć mniej bolesnych realizacji? Czy nie byłby bardziej racjonalny świat, w którym przestałyby istnieć przynajmniej niektóre formy cierpienia charakterystyczne dla świata, w którym żyjemy? Niewątpliwie, można by łatwo określić wolne od sprzeczności warunki, których spełnienie umożliwiłoby uniknięcie cierpień związanych z funkcjonowaniem totalitarnych struktur, z nienaruszaniem praw człowieka czy z wyzyskiem ekonomicznym. Przykład społeczeństw, w których warunki te zostały spełnione w stopniu względnie zadowalającym, chroni jednak przed pośpiesznym optymizmem. W społecznościach tych, przy statystycznym podejściu, na miejscu wcześniejszych problemów znalazły się nowe trudności związane z doświadczeniem bezsensu, frustracji czy zagubienia. Konieczność strukturalna, o której pisze Peacocke, ujawnia się wówczas nie w sposób deterministycznie jednoznaczny, co mogłoby sugerować fatalizm, lecz w sposób statystyczny, zwiększając prawdopodobieństwo wystąpienia określonych stanów stosownie do zmiany warunków początkowych. Poszukiwanie optymalnych ontycznych rozwiązań między wrażliwością potęgującą ból a bliską samozadowolenia bezmyślnością, między fizycznym cierpieniem chorego ciała a duchowym rozdarciem w odczuciu absurdalności zdarzeń, ma charakter tak wysoce spekulatywny, że trudno jest rozwijać tę tematykę bez popadnięcia w splątaną sieć subiektywnych przypuszczeń. 138.

${ }^{8}$ A. R. Peacocke, Science and the Christian Experiment, Oxford 1971 , 
Występowanie koniecznych ograniczeń strukturalnych pozwala znaleźć odpowiedź na pytanie, czy istnienie cierpienia i zła daje się pogodzić z filozoficzną tezą o racjonalnym charakterze świata. Oczywiście, nie wszystkie przejawy zła są następstwem nieuchronnych ograniczeń. W wielu przypadkach cierpienie pojawia się z powodu bezmyślnych czy nielogicznych działań wybranych przez człowieka. Kiedy pomija się jednak czynnik ludzkiej świadomości i poprzestaje na poziomie funkcjonowania praw fizyki czy biologii trzeba przyznać, iż struktura stanów, które są przyczyną cierpień nie prowadzi do obalenia tezy o istnieniu pojętego ontologicznie porządku świata. W rozwoju upośledzonego genetycznie dziecka dramat pojawia się na poziomie ludzkiej świadomości. W fizyko-biologicznych aspektach tego rozwoju można natomiast wskazać konieczność wzajemnych uwarunkowań między konkretnymi stanami. Uwarunkowania te konstytuują pewną strukturę, której wewnętrzna racjonalność różni się od racjonalności innych struktur z tej racji, iż hic et nunc inne były fizyczne czy biologiczne okoliczności rozwoju. Specyfika ludzkiego bytu przejawia się w tym, iż bezsens naszego istnienia może być odkrywany wśród struktur, którym przysługuje fizyczna sensowność i racjonalność. Równocześnie jednak szczególny charakter ludzkiego psychizmu znajduje wyraz w tym, iż potrafimy odkrywać całościowy głębszy sens, mimo wycinkowego doświadczenia bezsensu.

Z ostatnimi wnioskami doskonale korespondują zarówno zasady Whiteheadowskiej metafizyki wyrażone na kartach Modes of Thought, jak i refleksje Hartshorne'a zawarte w jego krytyce absurdyzmu Sartre'a. Whitehead podkreśla, iż nie można ująć sensu zdarzeń jeśli traktuje się je synchronicznie bez perspektywy czasowej i bez transcendującego wyjścia poza lokalną rzeczywistość chwilowych doznan. Sens zdarzeń jest odkrywany w kreatywności procesów, w których element bytowego niespełnienia łączy się z ukierunkowaniem w stronę przyszłości ${ }^{9}$. W perspektywach tych ideałem ludzkiej egzystencji nie jest egzystencja wolna od problemów lub nieskażona bólem. Z przedstawionej przez Whiteheada charakterystyki kategorii pokoju i piękna wynika, że o harmonii ludzkiej egzystencji można mówić dopiero wówczas, gdy mimo lokalnych zaburzeń doświadczanych w sytuacjach cierpienia i niepokoju człowiek potrafi tworzyć sens przez twórcze ukierunkowanie w stronę przyszłości,

?,A power of incorporating vague and disorderly elements of experience is essential for the advance into novelty. The understanding of the universe is rooted in the implications of this advance. Apart from it, creation is meaningless, divorced from change [...] The Universe is reduced to static futility" (Modes of Thought, New York 1968, 79). 
przez wprowadzenie innego układu odniesienia oraz skali uwzględnia-jącej otwarcie ludzkiego bytu na nieskończoność. W zakończeniu Adventures of Ideas autor wprowadza termin ,pokój” na oznaczenie tej „harmonii wszelkich harmonii, która wycisza destruktywne zakłócenia niosąc uzupełnienie dla cywilizacji" ${ }^{10}$. Zachowanie pokoju w obliczu dramatów zła i cierpienia jest wypadkową ludzkiej postawy i Bożej obecności. Zadaniem człowieka w sytuacjach dramatu i bólu jest „przede wszystkim zachowanie ufności w efektywność piękna", tzn. dążenie do postawy, w której usiłuje się szukać nadal sensu mimo zakłóceń niszczących budowaną harmonię. Doświadczenie pokoju nie jest jednak prostym efektem naszych działań. „Pokój ... przychodzi jako dar ... Jego rozległość sprawia, że znika nasze „ja”, zaś uwaga zostaje przeniesiona w dziedzinę bardziej rozległą niż osobowość" ${ }^{11}$. W tych rozległych perspektywach tworzy się ontyczna solidarność między cierpiącym człowiekiem a Bogiem, który poprzez sieć ujęć i odczuć pojawia się na horyzoncie naszego bólu. W ciągu naszych aktualnych zaistnień możemy wykluczyć Jego współdziałanie, np. przez wykorzystanie możliwości negatywnych ujęć i wtedy nasza ontyczna sytuacja będzie sytuacją Sartre'owskiego absurdu. Wszelkie próby jej uwznioślania przy pomocy Camusowskich komentarzy o pełnym godności Syzyfie są szlachetne w intencjach, lecz mało istotne. Skoro bowiem wszystko jest albo absurdem albo Syzyfowym wysiłkiem, to i zestawianie humanitarnych wskazówek dla Syzyfów jest także wysiłkiem absurdalnym ${ }^{12}$.

Filozofia procesu zajmuje stanowisko definitywnej opozycji zarówno w stosunku do pesymzimu Schopenhauera i absurdyzmu Sartre'a, jak i wobec współczesnych krytyków argumentujących, iż Whiteheadowskie wypowiedzi o poezji świata pozostają bezpodstawne, jeśli weźmie się pod uwagę rozmaitość cierpienia, nonsensu i łez doświadczaną w ludzkiej egzystencji. Przeciwko tezie o bezsensownym charakterze ludzkich cierpień można na gruncie metafizyki procesu wysunąć zarzut, iż sens jest rzeczywistością współkonstytuowaną przez człowieka oraz przez sieć złożonych ujęć, w których wypadło nam żyć i działać. Nasze doświadczenie sensu (resp. bezsensu) określonych sytuacji zależy w dużym stopniu od tego, czy podporządkujemy się biernie ciągom ujęć fizycznych naznaczonych piętnem niezależnych od nas uwarunkowań, czy też poprzez ujęcia pojęciowe będziemy starali się tworzyć trudną harmonię na horyzoncie naszego cierpienia.

Horyzont ten nie jest $\mathrm{w}$ ontologii Whiteheada miejscem niezawinionej

10 A. N. White hea d, Adventures of Ideas, New York 1961, $285 \mathrm{n}$.

11 Tamże.

${ }_{12} \mathrm{Ch}$. Hartshorne, Insights and Oversights of Great Thinkers, Albany $1983,334$. 
klęski. Ontycznych podstaw dla ludzkiej nadziei można w nim szukać zarówno w otwarciu $\mathrm{w}$ stronę transcendencji, jak i w niosącej zmianę kreatywności, która stanowi centralną kategorię metafizyki Whiteheada. W perspektywie ukazywanej przez tę metafizykę twórczy wysiłek człowieka łączy się $\mathrm{z}$ otwartością na dopełnienie egzystencjalnego „,jeszcze nie”, które będzie realizowane w przyszłych zdarzeniach i które może kształtować naszą nadzieję, mimo doświadczenia zła czy bezsilności ${ }^{13}$. W postawie metafizycznego otwarcia na nieskończoność, płynący czas przynosi wyzwolenie $\mathrm{z}$ dominacji zła. Bóg z zasady nie przeciwdziała złu uprzedzająco, np. poprzez zawieszenie praw fizyki. Jego naturalne przeciwdziałanie dokonuje się natomiast m.in. przy pomocy wyzwalającego działania czasu, który jest „,wiecznym przemijaniem” prowadzącym do nowej postaci świata.

Być może ewoluujący wszechświat musi w procesie swego rozwoju przejść przez obserwowane stadium intensywnej przemocy i bólu, podobnie jak przeszedł przez erę hadronową czy radiacyjną. Być może przyszłe etapy rozwoju przyniosą pełniejszą realizację naszych życiowych tęsknot za harmonią i sensem. Nie można jednak wykluczyć, iż niezależnie od stopnia realizacji tych tęsknot, niezupełność, zarówno w logice, jak i w bólu istnienia, pozostanie znakiem wskazującym na pełniejszy system, którego aspekty tylko w niewielkim stopniu sygnalizowane są w naszych interpretacjach. System ten pojawiałby się jako przejaw Boże! transcendencji odkrywanej wspólnie z Boskim Poetą świata nawet w poezji zdominowanej przez ból.

Zarówno Whitehead, jak i Hartshorne swych refleksji nad cierpieniem nie ograniczają do rozważań wyłącznie ontologicznych. W interdyscyplinarnym podejściu akcentują oni kulturowe aspekty ludzkiego przeżywania bólu. Szczególną uwagę kierują oni ku Ewangelii, analizując zawarta w niej prawdę o kondycji ludzkiej. W jej perspektywach solidarność Boga z człowiekiem w przeżywaniu cierpień ukazuje się w sposób szczególny w misterium Ukrzyżowania. Dramat Golgoty pozostaje w całej historii ludzkości wyjątkowym przykładem zespolenia elementu Boskiego $\mathrm{z}$ ludzkim. Zespolenie to przekształca dramat niewinnej śmierci w ekspresję miłości objawiającej głębszy sens. Nauka Golgoty ma w stanach naszego cierpienia przypominać o Boskim Współtowarzyszu cierpień u Którego we wtórnym aspekcie natury utrwalona zostaje rzeczywistośc naszych bolesnych doświadczeń ${ }^{14}$. Whitehead staje się niemal liryczny, gdy opisuje, jak „mądrość subiektywnych Bożych celów ujmuje wszelkie

18 Por. J. B. Cobb, Spiritual Discernment in A Whiteheadian Perspective w: Religious Experience and Process Theology, New York 1976, 356.

${ }_{14}$ Problematyke tę omawia Whitehead w eseju Immortality, [w:] The Philosophy of Alfred North Whitehead, New York 1951, 682-700. 
istnienie - jego cierpienia i ból, niepowodzenia i triumfy, wszystko co bezpośrednie w swej radości, splecione poprzez prawość odczuć w harmonię uniwersalnego czucia" ${ }^{15}$. Jego charakterystyka Boga, który solidarnie współdziała $\mathrm{z}$ człowiekiem, kontynuując dzieło zbawienia, jest bardzo bliska opisowi Izajasza 42,3. Swiadczą o tym sformułowania podkreślające, iż „Boży osąd jest osądem łagodności, która nie traci nic z tego, co może być uratowane. Jest On także osądem mądrości używającej tego, co w czasowym świecie jest jedynie wrakiem" ${ }^{16}$.

Whitehead widzi, jak kruche i niewystarczające są zwyczajne terminy metafizyki przy zetknięciu z rzeczywistością ludzkiego bólu. Dlatego też w refleksji nad tym bólem odwołuje się on nierzadko do pojęć teologicznych, gdy pisze np. o Królestwie Niebieskim, które już dziś realizuje się $\mathrm{w}$ nas $\mathrm{w}$ konkretnej intensywności naszych doświadczeń ${ }^{17}$. Sama świadomość obecności Królestwa nie musi czynić bólu mniej intensywnym. Pozostałby on bólem tragicznym, gdyby istnienie ludzkie nie było objęte przemieniającym strumieniem kreatywności, który prowadzi poza horyzont naznaczony niedoskonałością bólu. Ukierunkowanie w stronę innej doskonalszej rzeczywistości wnosi paradoksalny rys w naszą egzystencję, odsłaniając jej nowy wymiar i ukazując hierarchię wartości radykalnie różną od hierarchii sugerowanej przez czysty naturalizm. Jest to hierarchia ,porządku, który jest ponad naszym ziemskim istnieniem ... Przymierze z człowiekiem nie głosi, że będzie on ze swymi dziećmi pomyślnie prosperował $w$ historii. Raczej mówi, że umrą one wcześniej czy później, lecz żyć będą w porządku, który wykracza poza historię. Odziedziczą go cisi, miłosierni, czystego serca" ${ }^{18}$.

W perspektywach metafizyki procesu jako naturalna jawi się chrześcijańska doktryna o pleromie i paruzji. Ewoluujący wszechświat nie jest światem, który osiągnął doskonałość. Zdąża on w ustawicznym procesie w stronę swej pełni (completion). Byłby on wszechświatem niepełnym lub wręcz irracjonalnym, gdyby harmonia przyrody wyrażana w jej matematyczności czy stabilności praw fizyki załamywała się całkowicie na poziomie ludzkiej egzystencji. Miałoby to miejsce wówczas, gdyby jedyną formą ludzkiego życia było istnienie naznaczone cierpieniem ukierunkowanym ku bytowej nicości niesionej przez biologiczną śmierć. Postulat nieśmiertelności płynącej z ontycznej unii z Bogiem jawi się jako konieczny czynnik uniesprzeczniający ludzką egzystencję. Bez jego spełnienia cała ewolucja wszechświata byłaby wieńczona akcentami absurdu,

15 Process and Reality. An Essay in Cosmology, New York 1969, 408.

16 Tamże.

17 Tamże, 413.

18 S. H. Beer, The City of Reason, Cambridge 1949, 131. Autor tej pracy, profesor Uniwersytetu Harvarda, podejmował próby budowania filozofii społecznej na metafizyce Whiteheada. 
gdyż kreatywność prowadząca do powstania złożonych struktur prowadziłaby ostatecznie do ukształtowania świadomości po to, by człowiek mógł sobie uświadomić, iż jego racjonalne refleksje ukazują tragizm i nonsens bytu.

Wyjątkowa pozycja człowieka w przyrodzie przejawia się według metafizyki procesu również $\mathrm{w}$ tym, iż potrafimy odszukiwać sens, o którym nie mówią nic bezpośrednio dostępne dane empiryczne. Podczas gdy zwierzęta przewyższają nas w recepcji danych zmysłowych, specyficznie ludzkim doświadczeniem jest przeżycie etyczne czy estetyczne wyrażane np. w zachwycie nad pięknem kwiatu, który wyrósł na leśnej polanie ${ }^{19}$. Przeżycie to może łączyć się z doświadczeniem wartości, intuicją świętości, odczuciem sensu. Wykraczając poza sferę doznań empirycznych i ograniczeń cielesnych, człowiek potrafi tworzyć harmonię swej egzystencji poprzez odkrywanie sensu, który wymyka się czysto empirycznemu opisowi. Zdolność do poszukiwania sensu w sytuacjach największych zagrożeń, w doświadczeniu przemocy i zła, jest umiejętnością specyficznie ludzką, ukazującą człowieka jako animal aestheticum. Estetyka tego typu nie jest zbiorem abstrakcyjnych teoretycznych zasad, lecz umiejętnością praktycznego dążenia do piękna, które łączyłoby w jedną całość odwieczny konflikt między dobrem i złem, marzeniami i rzeczywistością, przejawami wolności i konieczności.

W ludzkim doświadczeniu cierpienia teoretyczny czynnik refleksji filozoficznej powinien znaleźć uzupełnienie $\mathrm{w}$ przeżywanej w kategoriach osobowych wierze religijnej. „Wiara ta - pisze L.S. Ford - jest zawierzeniem mimo wątpliwości, podtrzymywanym przez ufność, lojalność i oddanie. Przyszłość wydaje się ciągle wątpliwa, ryzykowna i niepewna. Niemniej człowiek wierzący podtrzymywany jest przez swe ufne oczekiwanie, że dobro zwycięży, jeśli tylko my wszyscy jako stworzenia będziemy wierzyć w Boga, tzn. polegać na Jego przewodnictwie (wprowadzanym w początkowym dążeniu każdego bytu) oraz ufać Mu do tego stopnia, aby realizować dobro, które proponuje On jako nową możliwość ... Mimo wszystko możemy ufać, iż Boska łaska może zostać przyjęta i przeniknąć wszelki byt" ${ }^{20}$.

Wyrazem braku krytycyzmu byłoby oczekiwanie, iż jakikolwiek system metafizyki może przynieść tłumaczenie wszystkich kwestii związanych z rzeczywistością ludzkiego cierpienia. Być może zasięg naszych tłumaczeń dotyczących tej tematyki jest uzależniony od stopnia filogenetycznego rozwoju naszego gatunku. Równolegle $\mathrm{z}$ tym rozwojem pojawiają się kwestie i próby odpowiedzi nie dostrzegane wcześniej przez naszych

19 Modes of Thought, 120.

${ }_{20}$ L. S. Ford, Divine Persuasion and the Triumph of God, w: Process Philosophy and Christian Thought, New York 1971, 297. 
przodków. Być może niektóre z filozoficznych aspektów problematyki cierpienia są niedostrzegane przez nas obecnie, podobnie jak w okresie kamienia łupanego człowiek pierwotny nie podejmował kwestii przygodności swego bytu. Być może dostrzeżenie nowych wymiarów cierpienia wymagać będzie rewolucji intelektualnej nie mniejszej od tej, która była potrzebna, by przejść od Nieruchomego Poruszyciela greckich racjonalistów do kochającego Boga Ewangelii św. Jana. Miłość do ograniczonych stworzeń jawiła się w teologii logicznych Greków jako szokująca niedoskonałość. Być może podobne mechanizmy sprawiają, iż $\mathrm{w}$ obecnym etapie rozwoju intelektualnego, zafascynowani racjonalnym dyskursem, tłumaczymy cierpienie $\mathrm{w}$ kategoriach niedoskonałości, pozostając niedostatecznie wrażliwi na ukrytą w nim wielkość.

Wśród teologicznych faktów, które przemawiałyby za ostatnią sugestią należy uwzględnić przede wszystkim to, iż Jezus objawiając w Swej misji elementarne prawdy niedostępne uprzednio dla ludzkiego intelektu wybrał cierpienie krzyża jako środek działania odkrywającego nowy wymiar bytu ${ }^{21}$. Cierpienie Boga-Człowieka, szokujące z punktu widzenia judaizmu czy teizmu filozofii greckiej, okazało się przełomowym wydarzeniem w historii ludzkości wprowadzając w nową niedostrzeganą wcześniej perspektywę. Cierpienie świata pozostaje ciągle szokujące dla naszego poczucia racjonalności zarówno $\mathrm{w}$ perspektywach teoretycznych rozważań, jak i w konkretnym doświadczeniu bólu. Swiat pojmowany przez Hartshorne'a jako ciało Boga partycypuje ciągle w tym bólu stanowiąc oczywisty znak, iż nasze dążenie w stronę pełni nie zostało jeszcze zrealizowane ${ }^{22}$. Ludzka moc włączania własnego bólu w proces kreatywnej przemiany świata wprowadza $\mathrm{w}$ naszą egzystencję rys moralnego piękna, w którym cierpiący człowiek tworzy wartości w sytuacji znacznie trudniejszej niż ma to miejsce w twórczości uczonego, muzyka czy artysty. Heroizm twórczego cierpienia przejawia się w tym, iż nie tracimy wiary w piękno nawet wówczas, gdy doświadczamy tragicznej dysharmonii między horyzontem teoretycznych możliwości i dostępnych faktycznie działań.

Przyjęta przez Hartshorne’a od Emersona koncepcja „moralnego piękna" może wydawać się przejawem niewłaściwego estetyzowania w obliczu bólu. Przed sformułowaniem podobnego zarzutu należy jednak dostrzec aksjologiczno-etyczne następstwa tej koncepcji. Nie można kwestionować faktu, iż w cywilizacji naszej cenimy harmonię logicznych konstrukcji

${ }^{21}$ Zob. Ch. Hartshorne, Reality as Social Process, Glencoe 1953, 135; Philosophers Speak of God, $162 \mathrm{n} ; A$ New Look at the Problem of Evil, [w:] Current Philosophical Issues: Essays in Honor of C. J. Ducasse, Springfield 1966. ${ }_{22} \mathrm{Ch}$. Hartshorne, Creative Synthesis and Philosophic Method, La Salle 1970, 241; Whitehead and Berdyaev: Is there Tragedy in God? „J. of Rel.", 37 (1957), 83. 
wyrażaną w spójnych teoriach naukowych czy harmonię piękna utrwaloną w dziełach El Greco, Mozarta lub Szekspira. Od harmonii tych znacznie trudniejsza jest niedoceniona $\mathrm{w}$ naszej cywilizacji harmonia egzystencji, w której doświadczenie bólu nie jest w stanie zniszczyć doświadczenia sensu. Postawa ta jest tym trudniejsza, gdyż w twórczości artysty lub uczonego istotna jest jedynie jednoaspektowa harmonia wyrażana w związkach wynikania logicznego lub w estetyce konstrukcji. W sytuacji cierpienia musi zachodzić znacznie trudniejsza harmonia wszystkich aspektów bytu doświadczanych przez cierpiącą osobę.

Być może gdyby w kulturowym rozwoju ludzkości większą rolę odgrywały elementy ewangeliczno-sokratejskie potrafilibyśmy dostrzegać przejawy geniuszu i wielkości w samotniczych zmaganiach $\mathrm{z}$ cierpieniem. Cywilizacja nasza przejęła jednak odmienne kryteria wartościowań pozostające nierzadko $\mathrm{w}$ rażącej dysharmonii z tezą o racjonalnym charakterze ludzkiej natury. Porównując przerażające dysproporcje między troską o harmonię fizyczną, wyrażaną choćby w dowartościowaniu sportu, a zainteresowaniem harmonią psychiczną, np. u nieuleczalnie chorych, można łatwo dojść do pesymistycznych ocen stopnia naszego rozwoju kulturowego. Nasza troska o rytualną harmonię wyrażaną zarówno w zasadach savoir-vivre'u jak i w celebrze otaczającej dostojników, rozpatywana na tle samotniczych zmagań z cierpieniem zdaje się świadczyć, iż powierzchowna wrażliwość estetyczna rozwinęła się w naszym gatunku szybciej niż wrażliwość etyczna. W wyniku tej właśnie wrażliwości w zmieniającym się kontekście konkretnych ludzkich cierpień powracać będą zawsze nowe warianty pytania Iwana Karamazowa, czy cała doskonałość świata jest w stanie zrównoważyć ból cierpiącego niewinnie dziecka.

Próby pozytywnej odpowiedzi na to pytanie można by oceniać sceptycznie, gdyby cała rzeczywistość ludzkiej egzystencji była ograniczona przez niedoskonałość niosącą cierpienie. Tymczasem w Whiteheadowskiej metafizyce procesu, podobnie jak w klasycznym ujęciu filozofii chrześcijańskiej, teza o istnieniu rzeczywistości innego poziomu wprowadza w perspektywę Ostatecznego Sensu. Po uwzględnieniu faktów nieskończonego trwania ludzkiej egzystencji i skończności wszelkich cierpień otrzymujemy nowy układ odniesienia dla hierarchii naszych wartościowań. W układzie tym to, co było najwyższą tragedią w czysto naturalistycznej perspektywie, staje się elementem składowym wyższej, niedostrzegalnej uprzednio harmonii. Próby podtrzymywania w nim opozycji między nieczułym Bogiem i cierpiącym niewinnie człowiekiem są wynikiem nieporozumienia. Przyjęcie kategorii metafizyki procesu wprowadza bowiem na miejsce tradycyjnej opozycji ontyczne zespolenie. Łączy się w nim konieczność praw i nieuchronnych ograniczeń z możliwością ludzkiego. 
wyjścia poza niektóre z tych ograniczeń w celu poszukiwania nowego sensu ${ }^{23}$. Najważniejszy zaś pozostaje fakt, iż w ciągach zdarzeń naznaczonych przez ból, cierpiący człowiek łączy się w ontycznym związku z Bogiem, współtowarzyszem naszych cierpień, aby tworzyć najtrudniejszą wielką Harmonię.

\section{THE PROBLEM OF SUFFERING IN THE FRAMEWORK OF WHITEHEADIAN PROCESS PHILOSOPHY}

\section{S u m m a r y}

Sharing the opinion that the explicative power of different philosophical systems depends on their languages and basic assumptions, the author raises the question whether the existing human suffering cannot be explained in Whiteheadian metaphysics in a more adequate manner than in the systems of classical philosophy. After presenting basic terms introduced in Whitehead's Process and Reality the author develops some Hartshornian ideas dealing with the divine solidarity with suffering men and investigates A. R. Peacocke's comments on the so-called structural necessity. Metaphysical interpretations of the limitative theorems discovered in metalogic are proposed to approach some forms of suffering as an ontic necessity unavoidable for the same reasons which determine uncompleteness of consistent logical systems.

${ }^{23}$ Przedstawiona interpretacja, w której pewne formy cierpienia są traktowane jako przejaw ontycznej konieczności, może budzić zastrzeżenia z racji jej pozornego konfliktu z klasyczną doktryną chrześcijańską dotyczącą Bożej wszechmocy. Bezpodstawność podobnych zastrzeżeń starałem się wykazać $\mathrm{w} V \mathrm{~V}$ rozdz. 2. tomu pracy Teizm i filozofia analityczna. Argumentuję tam m.in. iż niemożność istnienia świata materialnego, w którym nie występowałyby ograniczenia niosące cierpienie nie upoważnia do kwestionowania Bożej wszechmocy. Wchodzą tu w grę racje podobne do tych, przez które nie można np. podważać tezy „Bóg jest wszechmocny” przez proste odwołanie się do faktu, iż Bóg nie może sprawić, aby w spójnym systemie logicznym uznawane było zarówno twierdzenie $\mathrm{p}$, jak i jego negacja $\sim$ p. Część przedstawionej argumentacji można by uniezależnić od systemu filozofii Whiteheada, pozostając wyłącznie przy odwołaniu do twierdzeń limitacyjnych. Argumenty nawiązujące do tych twierdzeń jawią się jednak jako naturalna konsekwencja w perspektywach filozofii procesu, gdyż metafizyka Whiteheada ma de iure stanowić najbardziej ogólną, racjonalną interpretację rzeczywistości, w której uniwersalne relacje i związki są ujmowane bez względu na to, czy występują one w przyrodzie, czy też w dziedzinie obiektów matematyki. Podobna epistemologia metafizyki stwarza naturalną podstawę do tego, by przy poszukiwaniu elementarnych zasad rzeczywistości szukać na poziomie bytu realnego odpowiedników twierdzeń limitacyjnych metalogiki. 